\title{
A journey to a brighter future
}

\author{
Gang Pei ${ }^{1}$ \\ ${ }^{1}$ Institute of Biochemistry and Cell Biology, Shanghai Institutes for Biological Sciences, Chinese Academy of Sciences, 320 Yueyang \\ Road, Shanghai 200031, China
}

Cell Research (2006) 16:1-2. doi:10.1038/sj.cr.7310001; published online 16 January 2006

It has been 15 years since Cell Research was launched in 1990. At that time, Chinese scientists rarely published their work in non-Chinese journals, and China did not have a major English journal of its own in life sciences. In a way, Cell Research was born at the right time, in the right place, and with the right kind of people guiding its development. The rise of Cell Research as China's leading journal publishing peer-reviewed articles in basic life sciences has paralleled the rapid development of the Chinese economy in general and the science and technology sector in particular over the same period. The current economic trend should allow even more rapid advances in the life sciences which will ensure a healthy growth of Cell Research in years to come. Thus, we are confident that Cell Research has a brighter future.

The success of Cell Research today would not have been possible without the tremendous contribution by one distinguished scientist, Professor Zhen Yao. Professor Yao was the founding Editor-in-Chief of Cell Research and served in this role until he passed away a month ago at the age of 90 . I could only imagine how much arduous work he had to put in at the age of 75 while launching this journal, and I have personally witnessed his great efforts in the last ten years as he cared for the journal like one of his own grandchildren.

Under his care, Cell Research has grown from what was initially a semiannual publication, to a quarterly, then a bimonthly and, now, a monthly. His invaluable contribution to the development of Cell Research will always be remembered. Many others have helped Cell

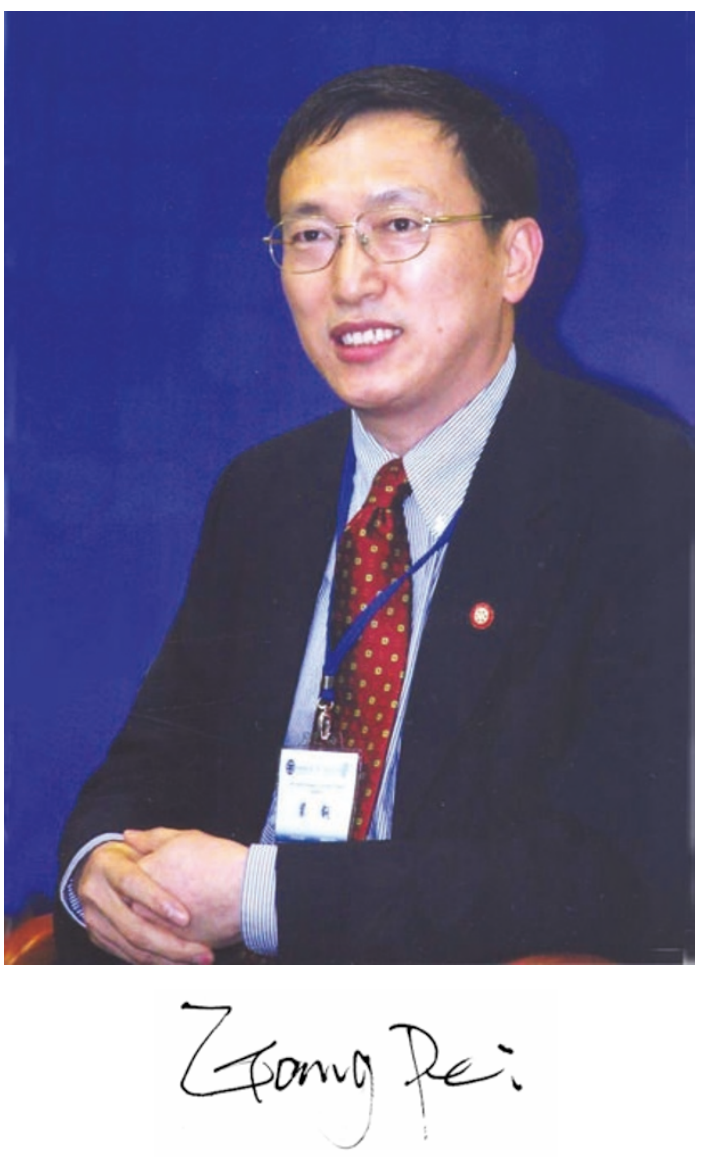

Research during its 15-year's history as well. I would particularly like to acknowledge the enormous contributions from the last deputy Editor-in-Chief, Professor Min Yeh, our Associate Editors, especially Drs Yun-Bo Shi, Yufang Shi, and Lu Liang; as well as our Managing Editor, Ms Ailan 
Chang; and all the members of the Editorial Board. With the sad passing of Professor Yao, I will be taking on the editorial leadership of Cell Research. To help me in this task, there will be a new Editorial Board. I am confident that together we will work towards a better and brighter future for this journal.

Currently, Cell Research has a relatively good Impact Factor and is also indexed and/or abstracted by the major worldwide biomedical databases. Cell Research has recently signed a partnership agreement with Nature Publishing Group (NPG), thus, is now published by NPG as a partner journal starting from this issue. This new partnership will provide many benefits to our authors and readers. Papers published in the journal will enjoy much better exposure, more press coverage and quicker publication than before through nature.com. Readers of the journal worldwide will be able to access the best research from China. At the mean time, the number of contributions from highly-respected scientists throughout the world is expected to increase with the committed support from NPG. Science is a truly international discipline and in keeping with this spirit Cell Research will continue to aim to become a leading international journal in life sciences with a specific emphasis on basic cell biology and molecular cell biological research.

The journey to reach this goal is likely to be a long one but the outcome of this journey is certain. I have no doubt that Cell Research will continue to grow and prosper as a journal of, by, and for the global scientific community.

\section{A brief introduction of the new Editor-in-Chief}

Dr Gang Pei is a Professor and the President of Shanghai Institutes for Biological Sciences (SIBS), Chinese Academy of Sciences (CAS). He obtained his B.Sc. in Pharmacy in 1981 and M.Sc. in Pharmaceutical Sciences in 1984 from Shenyang College of Pharmacy, Shenyang, China. He then conducted research in the Department of Clinical Pharmacology, Karolinska Institute, Stockholm, Sweden as a visiting fellow in 1986. He subsequently obtained his Ph.D. in Biochemistry and Biophysics from University of North Carolina at Chapel Hill in 1991. Dr Pei undertook his post-doctoral training in Cell Biology and Signal Transduction at Duke University unti he was recruited as a Research Group Leader at Shanghai Institute of Cell Biology, cosponsored by Chinese Academy of Sciences and the German Max-Planck Society in 1995.

Dr Pei's research has focused on regulation of G protein-coupled receptor signaling and its role in epigenetics; crosstalk between distinct cellular signaling pathways; the molecular, cellular, and neural mechanisms of opiate addiction; and the elucidation of the molecular mechanisms that underlie the efficacy of traditional Chinese medicine. Dr Pei was elected to the Chinese Academy of Sciences in 1999 and the Third World Academy of Sciences (TWAS) in 2001. Currently, he serves as the president of Shanghai Institutes for Biological Sciences (SIBS), Chinese Academy of Sciences (CAS) and the president of Chinese Society of Cell Biology (CSCB). Dr Pei jointed the Editorial Board of Cell Research as an Associate Editor-in-Chief in 2002, and he now succeeds Professor Zhen Yao as the Editor-in-Chief of Cell Research in Jan 2006.

\section{Recent Publications (Selected)}

1 Wang Y, Tang Y, Teng L, Wu Y, Zhao X, Pei G. Nat Immunol 2005 Dec 25; [Epub ahead of print]

2 Kang J, Shi Y, Xiang B, Qu B, Su W, Zhu M, Zhang M, Bao G, Wang F, Zhang X, Yang R, Fan F, Chen X, Pei G, Ma L. Cell 2005; 123:833-47.

3 Luan B, Zhang Z, Wu Y, Kang J, Pei G. EMBO J 2005; 24:4237-46.

4 Guan JS, Xu ZZ, Gao H, He SQ, Ma GQ, Sun T, Wang LH, Zhang ZN, Lena I, Kitchen I, Elde R, Zimmer A, He C, Pei G, Bao L, Zhang X. Cell 2005; 122:619-31.

5 Xu NJ, Yu YX, Zhu JM, Liu H, Shen L, Zeng R, Zhang X, Pei G. J Biol Chem 2004; 279:40601-8.

6 Wang P, Gao H, Ni Y, Wang B, Wu Y, Ji L, Qin L, Ma L, Pei G. J Biol Chem 2003 ; 278:6363-70.

7 Xu NJ, Bao L, Fan HP, Bao GB, Pu L, Lu YJ, Wu CF, Zhang X, Pei G. J Neurosci 2003; 23:4775-84.

8 Wang P, Wu Y, Ge X, Ma L, Pei G. J Biol Chem 2003; 278:11648-53. 